This item was submitted to Loughborough's Research Repository by the author.

Items in Figshare are protected by copyright, with all rights reserved, unless otherwise indicated.

\title{
Allowable $\mathrm{CO} 2$ emissions based on regional and impact-related climate targets
}

PLEASE CITE THE PUBLISHED VERSION

http://dx.doi.org/10.1038/nature16542

PUBLISHER

(C) Nature Publishing Group

VERSION

AM (Accepted Manuscript)

\section{PUBLISHER STATEMENT}

This work is made available according to the conditions of the Creative Commons Attribution-NonCommercialNoDerivatives 4.0 International (CC BY-NC-ND 4.0) licence. Full details of this licence are available at: https://creativecommons.org/licenses/by-nc-nd/4.0/

\section{LICENCE}

CC BY-NC-ND 4.0

\section{REPOSITORY RECORD}

Seneviratne, Sonia I., Markus G. Donat, Andy J. Pitman, Reto Knutti, and Robert Wilby. 2016. "Allowable CO2 Emissions Based on Regional and Impact-related Climate Targets”. Loughborough University. https://hdl.handle.net/2134/20492. 
1 Allowable $\mathrm{CO}_{2}$ emissions based on regional and impact-related climate targets

3 Sonia I. Seneviratne ${ }^{1}$, Markus G. Donat ${ }^{2,3}$, Andy J. Pitman ${ }^{2,3}$, Reto Knutti ${ }^{1}$, and Robert L.

4 Wilby $^{4}$

$6 \quad{ }^{1}$ Institute for Atmospheric and Climate Science, ETH Zurich, Switzerland

$7 \quad{ }^{2}$ ARC Centre of Excellence in Climate System Science, University of New South Wales,

8 Sydney, Australia

$9{ }^{3}$ Climate Change Research Centre, University of New South Wales, Sydney, Australia

$10{ }^{4}$ Department of Geography, Loughborough University, UK

12 Global temperature targets, such as the widely accepted $2^{\circ} \mathrm{C}$ limit, may fail to

13 communicate the urgency of reducing $\mathrm{CO}_{2}$ emissions. Translation of $\mathrm{CO}_{2}$ emissions

14 into regional- and impact-related climate targets could be more powerful because

15 they resonate better with national interests. We illustrate this approach using

16 regional changes in extreme temperatures and precipitation. These scale robustly

17 with global temperature across scenarios, and thus with cumulative $\mathrm{CO}_{2}$ emissions.

18 This is particularly relevant for changes in regional extreme temperatures on land,

19 which are much greater than changes in the associated global mean.

21 The IPCC $5^{\text {th }}$ Assessment Report included a figure in the Summary for Policymakers

22 (SPM) of the Working Group 1 (WG1) that linked global mean temperature changes

$23\left(\Delta \mathrm{T}_{\text {glob }}\right)$ to total $\mathrm{CO}_{2}$ emissions from 1870 onwards $^{1}$ (Fig. 1). This figure is compelling 
24 because it shows a clear linear relationship between cumulative $\mathrm{CO}_{2}$ emissions and a

25 measure of the global climate response. The obvious consequences are that every ton of

$26 \mathrm{CO}_{2}$ contributes about the same amount of global-scale warming, no matter when it is

27 emitted, that any target for the stabilization of $\Delta \mathrm{T}_{\text {glob }}$ implies a finite $\mathrm{CO}_{2}$ budget or quota

28 that can be emitted, and that global net emissions at some point need to be zero ${ }^{2,3,4,5,6}$.

30 This simple relationship between $\mathrm{CO}_{2}$ emissions and changes in $\Delta \mathrm{T}_{\text {glob }}$ (Fig. 1) has helped

31 overcome one communication barrier for the public in relating greenhouse gas emissions

32 with the climate system response. Yet, another obstacle remains the actual appreciation of

33 associated climate impacts, namely the translation of changes in global mean temperature

34 to regional-scale consequences for society and the environment. In this Perspective, we

35 demonstrate the feasibility of - as well as make the case for - quantitatively relating

36 global-scale cumulative $\mathrm{CO}_{2}$ emissions to regional climate targets. We illustrate this

37 approach by scaling changes in hot and cold extreme temperatures and heavy

38 precipitation events with changes in the global mean temperature.

\section{Global vs regional climate targets}

41 Our experience shows that the implications of projected global mean temperature

42 changes tend to be underestimated at regional (and country) level, because these are

43 much smaller than the expected changes in regional temperature mean and extremes over

44 most land areas ${ }^{7,8,9,10}$. The limitations of focusing on global mean temperature as a

45 measure of climate change has, for instance, been evidenced by the public debate about 
46 the recent "hiatus". This has fixated attention on changes in $\Delta \mathrm{T}_{\text {glob }}$ instead of the

47 discernible worldwide impacts of the continued increases in radiative forcing ${ }^{1}, 11,12,13,14$.

49 As illustrated in Fig. 2 , a $2{ }^{\circ} \mathrm{C}$ target for $\Delta \mathrm{T}_{\text {glob }}$ implies increases in both warm and cold

50 temperature extremes greater than $2^{\circ} \mathrm{C}$ over most land regions. This is due to the land-sea

51 contrast ${ }^{15,16}$ in response to radiative forcing, as well as to feedbacks (e.g. from decreases

52 in soil moisture, snow, or ice ${ }^{7,8,17,18,19,20}$ ), which further amplify changes in extreme

53 temperatures in some key regions. As an example, the $2^{\circ} \mathrm{C}$ global mean temperature

54 target implies $3^{\circ} \mathrm{C}$ warming in hot temperature extremes in the Mediterranean region (Fig.

55 2a) and ca. $5.5^{\circ}$ warming in cold temperature extremes over land in the Arctic region (Fig.

56 2b). Hence, these changes in regional extremes are greater than those in global mean

57 temperature by a factor of ca. 1.5 and 2.5 to 3 (Supplementary Figure S1), respectively.

58 As highlighted above, this stronger warming of extremes on land compared to that of

59 global mean temperature is related both to the larger warming of mean temperature on

60 land (Fig. 2c), as well as to an additional specific warming of extremes in several regions

61 (Figs. 2a,b). Subjectively, such regional changes in extremes may better convey the

62 consequences of crossing the respective cumulative $\mathrm{CO}_{2}$ emissions threshold, compared

63 to the associated change in $\Delta \mathrm{T}_{\text {glob }}\left(2^{\circ} \mathrm{C}\right)$, which appears relatively mild in comparison.

65 We make the case here for more easily interpretable analyses that relate global

66 cumulative $\mathrm{CO}_{2}$ emissions targets to changes in regional extremes or other impact-

67 relevant quantities in addition to changes in global mean temperature. While the IPCC

68 Synthesis Report ${ }^{21}$ has shown cumulative $\mathrm{CO}_{2}$ emissions alongside the famous "reasons 
69 for concerns", the employed bars of various degrees of red only provide a qualitative

70 assessment. We highlight hereafter how quantitative analyses relating cumulative

71 emissions to climate change at the national or regional scale could provide more targeted

72 and actionable information for the decision process.

\section{Relating extremes to global $\mathrm{CO}_{2}$ emissions}

75 We thus assess the extent to which the implications of Fig. SPM.10 (Fig. 1) from the

76 IPCC AR5 WG1 $\mathrm{SPM}^{1}$ can be expanded to relate cumulative global emissions in $\mathrm{CO}_{2}$

77 with regional changes in temperature extremes (annual maximum and minimum

78 temperatures, see Box 1). The result is displayed in Fig. 3 for four example regions with

79 relatively strong scaling (Mediterranean basin, contiguous U.S., and Brazil for annual

80 maximum daytime temperatures; the Arctic for annual minimum nighttime temperatures;

81 for other regions, see Supplementary Figures S4 and S5). The analyses display the

82 scaling of the considered regional changes with the changes in global mean temperature

83 for a range of climate projections, and provide the associated expected allowable

84 cumulative global $\mathrm{CO}_{2}$ emissions (but without considering the uncertainty in translating

$85 \Delta \mathrm{T}_{\text {glob }}$ to cumulative emissions).

86

87 The results show that changes in regional extreme temperatures display a rather linear

88 scaling with $\Delta \mathrm{T}_{\text {glob }}$, which is also mostly independent of the emission scenario considered

89 (Fig. 3). Hence, regional changes in temperature extremes can be usefully related to given

90 cumulative $\mathrm{CO}_{2}$ targets, without any consideration of the emission pathway. However,

91 scaling for regional extremes on land is generally steeper than for $\Delta \mathrm{T}_{\text {glob }}$ (see also 
92 analyses for other land regions in Supplementary Figures S4 and S5). Hence, as expected

93 from Fig. 2, the relationship between the increase in regional temperature extremes and

94 the increase in global mean temperature typically implies a larger change of the former at

95 more local scales.

97 For instance, a $2^{\circ} \mathrm{C}$ warming in hot extremes (annual warmest daytime temperature, $\mathrm{TXx}$ )

98 takes place in the Mediterranean for a change of $1.4^{\circ} \mathrm{C}$ in $\Delta \mathrm{T}_{\text {glob }}$ (Fig. 3a). The

99 corresponding allowable cumulative $\mathrm{CO}_{2}$ emissions are therefore $600 \mathrm{GtC}$ for a $2{ }^{\circ} \mathrm{C}$

100 warming of hot extremes in the Mediterranean region compared to ca. $750-800$ for a $2^{\circ} \mathrm{C}$

101 warming in global mean. Given current political tensions around the Mediterranean basin,

102 implications of locally more rapid climate change could extend to regional impacts ${ }^{22}$,

103 adding to wider political instability (see for example the purported impacts of drought in

104 Syria $\left.^{23,24}\right)$.

105

106 Scaling extreme hot temperatures in the contiguous U.S. and Brazil (Figs. $3 b, c)$ by $\Delta \mathrm{T}_{\text {glob }}$

107 provides qualitatively similar results, but highlights greater uncertainty of projections in

108 these regions. In the contiguous U.S., although the expected value of scaling with $\Delta \mathrm{T}_{\text {glob }}$

109 is greater than 1 , the uncertainty range bounds the $1: 1$ line. Conversely, the regional

110 response in Brazil is significantly different from the 1:1 line despite the larger uncertainty

111 range compared to the Mediterranean region. The response of the regional changes in

112 annual coldest daily temperatures (TNn) in the Arctic (Fig. 3d) conveys a very stark

113 message. In this case, as seen in Fig. 2, the regional response is ca. 2.5-3 times greater for

114 the coldest extremes than for the global mean temperature change, with an increase of 
115 about $5.5^{\circ} \mathrm{C}$ for the $2^{\circ} \mathrm{C}$ global warming target. In addition, it is evident that a regional

$1162{ }^{\circ} \mathrm{C}$ threshold was passed in the simulations around year 2000 for TNn in the Arctic,

117 while it is projected to be reached by ca. 2030 for TXx in the Mediterranean, Brazil and

118 the contiguous U.S., and only by the mid-2040s for the global mean temperature, under

119 the business-as-usual (RCP8.5) emissions scenario.

120

121 While we illustrated the concept of regional and impact-related climate targets with

122 regional changes in temperature extremes, similar reasoning can be applied to a range of

123 other responses to global climate forcing ${ }^{7,25}$ (e.g. changes in heavy precipitation events,

124 see hereafter). These are also highly relevant in comprehending the regional implications

125 of global $\mathrm{CO}_{2}$ emissions. As a further illustration, we display in Fig. 4 the scaling of

126 heavy precipitation events with global mean temperature, and the respective relationship

127 between cumulative $\mathrm{CO}_{2}$ emissions and resulting changes in heavy precipitation in

128 Southern Asia. As for regional temperature extremes, multi-model average changes in

129 heavy precipitation display an almost linear scaling with the global mean temperature ${ }^{26}$

130 (roughly consistent with the Clausius-Clapeyron relationship in that region), and thus

131 could be used to inform regional decision-makers on suitable allowable targets for global

132 emissions. Moreover, it should be noted that, while the ensemble mean response is robust

133 across models and emissions scenarios, individual model projections can diverge strongly

134 from this mean response (in the investigated region as well as in other locations, see

135 Supplementary Figures S6 and S7). This point is denoted by the red-shaded uncertainty

136 range, which, in most regions, is substantially larger than for temperature extremes. This

137 behaviour is due to the increasing relevance of internal climate variability at regional-to- 
138 local scale ${ }^{27}$, higher model uncertainty, and the spatially more heterogeneous nature of

139 precipitation extremes compared to temperature extremes.

141 Despite the associated uncertainty, analyses such as the ones in Figs. 3 and $4 \mathrm{~b}$ provide

142 more information to regional stakeholders than a global mean temperature target, since

143 they quantitatively and directly highlight the expected regional response (in extremes and

144 other variables than temperature), with attendant lower and upper bounds. Such estimates

145 are thus more useful when assessing associated impacts, and engaging with policymakers.

\section{Limitations of approach}

148 Some caveats are attached to the above findings, most importantly:

149 1. Scaling relationships are only meaningful as long as associated uncertainties in

150 projections are kept within reasonable bounds. This is the case for some climate

151 features, such as temperature extremes or heavy precipitation events ${ }^{1,7}$, but for

152 others, such as droughts, tropical cyclones, or storms, uncertainties are generally

153 larger than the climate change signals ${ }^{1,7,28}$. In such situations, no emissions target

154 (or implied global temperature target) may currently be set based on avoiding

$155 \quad$ changes in these extremes.

1562 2. Some changes in the climate system may be abrupt (i.e. non-linearly related to

157 emissions) due to tipping points ${ }^{29}$. Again, uncertainties in the associated

158 projections are very large, especially under high-end emissions. Due to the non-

159 linearity of the respective features, relationships could be difficult to derive

160 (although some features have been assessed, such as the dependency of mean sea 
161 level rise on global mean temperature increase at equilibrium ${ }^{30}$ and the probability 162 of abrupt changes for given global temperature thresholds ${ }^{31}$ ).

163 3. Although we find a relatively robust scaling of regional-scale temperature and 164 precipitation extremes with $\Delta \mathrm{T}_{\text {glob }}$, we can expect that the reliability of scaling 165 will diminish at increasingly smaller scales due to internal climate variability ${ }^{27,32}$ 166 and a larger contribution of local processes to the response (including by local 167 land surface and human forcing, see point 5.).

168 4. It is likely that climate models share common biases for some regional climate 169 phenomena $a^{33,34,35,36}$. In this case, scaling features could be derived, but would be 170 erroneous; an issue that would need to be examined with careful model 171 evaluation ${ }^{37,38}$ contingent on the availability of appropriate observations.

1725 . The relationship between changes in regional climate and $\Delta \mathrm{T}_{\text {glob }}$ would be 173 expected to alter in the presence of time-varying local forcing by, for example, 174 aerosols $^{39}$, land use and land cover change ${ }^{40,41,42}$, urban development ${ }^{43}$, or human $175 \quad$ water use $e^{44,45}$. These effects are likely to play an important role on local scale, but 176 less for the larger regions considered here (Figs. 3 and 4 and regions from the 177 IPCC Special Report on Extremes $\left(\mathrm{SREX}^{7}\right)$ in Supplementary Information).

178 6. The ranges in Fig. 3 and Fig. $4 \mathrm{~b}$ reflect the uncertainty in the scaling of the 179 regional quantities with $\Delta \mathrm{T}_{\text {glob }}$, but do not include uncertainties associated with 180 the scaling of $\Delta \mathrm{T}_{\text {glob }}$ with the cumulative $\mathrm{CO}_{2}$ emissions (Fig. 1). This additional 181 uncertainty source is also relevant for the decision process when assessing 182 regional climate targets (as is the case for climate targets based on the global 183 mean temperature). For a given impact threshold, the uncertainty in the 
cumulative carbon would be wider, and as a consequence the cumulative carbon budget would be smaller if the desire were to avoid the impact with high probability ${ }^{5}$. More in-depth analyses of the CMIP5 archive would help determine the total uncertainty range when directly relating imposed greenhouse gas forcing to simulated regional extremes.

\section{Using regional targets in decision making}

191 We focus here on regional changes because local stakeholders and decision-makers are

192 more likely to be able to relate to them than to global mean temperature changes.

193 However, we stress that this does not imply that countries should only be concerned

194 about climate changes affecting them directly in a geographical sense. Indeed, because of 195 globalization, major climate disruptions in some countries can strongly affect others, for

196 instance due to political unrest, migration, impacts on global food production, supply

197 chains and trade ${ }^{23,46,47}$. Even when not directly affected by given changes, individual

198 countries are more likely to understand the implications of respective climate targets for

199 other parties if they can more readily quantify their implications for different regions.

200 This could also help pave the way to solutions that integrate both climate mitigation and

201 adaptation within climate negotiations, by incorporating the avoided costs of impacts in

202 negotiations when discussing the costs of mitigation. In this context, it is possible that

203 different (and possibly lower global targets ${ }^{48,49,50}$ ) than $2^{\circ} \mathrm{C}$ may well be desirable. 204

205 Linking cumulative $\mathrm{CO}_{2}$ emission targets to regional consequences, such as changing 206 climate extremes, would be of particular benefit for political decision making, both in the 
207 context of climate negotiations and adaptation. We stress that the quantification of

208 regional targets will not necessarily imply that involved parties will agree on the suitable

209 (and common) cumulative global $\mathrm{CO}_{2}$ emission target. However, this information can

210 help in the development of solutions and in the communication with the public. Similarly

211 robust regional scaling might be expected for other features of the climate system beside

212 those considered here ${ }^{51,52}$, and could be explored for impact-based simulations ${ }^{53,54,55}$.

213 Indeed, such relationships can be determined for any regional and/or impact-relevant

214 climatic feature that scales robustly with changes in global mean temperature (or is at

215 least monotonically related to it), and which is not associated with larger uncertainty

216 ranges or biases in current climate models.

218 In view of the inherent model uncertainty and in order to avoid possible risks associated

219 with the indiscriminate use of such information, we recommend that IPCC calibrated

220 language be applied when assessing the confidence of any such derived relationships,

221 with only situations of high confidence justifying derivation of quantitative estimates ${ }^{7}$. In

222 addition to the requirement of high confidence levels, high signal to (model) noise ratio

223 (traditionally referred to in likelihood terms in the IPCC language ${ }^{7}$ ) is a prerequisite for

224 deriving meaningful allowable $\mathrm{CO}_{2}$ emissions ranges. Furthermore, any assessment of

225 projected changes in climate risks and impacts also needs to consider the contributions of

226 changes in vulnerability and exposure of human and natural systems to those climate

227 hazards ${ }^{25}$. Bearing in mind these requirements, quantitative tools for decision making that

228 relate regional (or even country-scale) impacts to global $\mathrm{CO}_{2}$ emissions targets could be

229 one way of advancing climate negotiations by more locally exposing what is at stake. 


\section{References}

231 1. IPCC. Summary for Policymakers. In: Climate Change 2013: The Physical Science

232 Basis. Contribution of Working Group I to the Fifth Assessment Report of the

233 Intergovernmental Panel on Climate Change [Stocker, T.F., et al. (eds.)], pp. 3-29.

234 Cambridge University Press, Cambridge, United Kingdom and New York, NY, USA

235 (2013).

236 The Summary for Policymakers of the IPCC AR5 working group 1 report

237 (approved line by line by the IPCC plenary) includes for the first time a figure

238 relating cumulative $\mathrm{CO}_{2}$ emissions with projected changes in global mean

239 temperature (Fig. 1 in the present article). It builds upon refs ${ }^{2,3,4}$ and more

240 recent simulations and publications on this topic.

241 2. Meinshausen, M., et al. Greenhouse-gas emission targets for limiting global warming

242 to $2^{\circ} \mathrm{C}$. Nature, $458,1158-1162(2009)$.

243 3. Allen, M.R., et al. Warming caused by cumulative carbon emissions towards the

$244 \quad$ trillionth tonne. Nature, 458, 1163-1166 (2009).

245 4. Matthews, H.D., Gillett, N.P., Stott, P.A., \& Zickfeld, K. The proportionality of

246 global warming to cumulative carbon emissions. Nature, 459, 829-832,

247 doi:10.1038/nature08047 (2009).

248 5. Knutti, R., \& Rogelj, J. The legacy of our $\mathrm{CO}_{2}$ emissions: A clash of scientific facts,

249 politics and ethics. Climatic Change, doi:10.1007/s10584-015-1340-3 (2015).

250 6. Friedlingstein, P., et al. Persistent growth of $\mathrm{CO}_{2}$ emissions and implications for

251 reaching climate targets. Nature Geoscience, 7, 709-715 (2014). 
252 7. Seneviratne, S.I., et al. Changes in climate extremes and their impacts on the natural

253 physical environment. In: Managing the Risks of Extreme Events and Disasters to

254 Advance Climate Change Adaptation [Field, C.B., et al. (eds.)]. A Special Report of

255 Working Groups I and II of the Intergovernmental Panel on Climate Change, pp. 109-

256 230. Cambridge University Press, Cambridge, United Kingdom and New York, NY,

$257 \quad$ USA (2012)

258 8. Orlowsky, B., \& Seneviratne, S.I. Global changes in extreme events: Regional and

259 seasonal dimension. Climatic Change, 110, 669-696, doi: 10.1007/s10584-011-0122-

$2609(2012)$.

261 This article provides an analysis of the scaling of changes in regional

262 temperature extremes with changes in global warming, as well as its

263 decomposition in several contributing factors (regional, seasonal, and

264 differential response of extremes vs median).

265 9. Lehner, F., \& Stocker, T.F. From local perception to global perspective. Nature

266 Climate Change, 5, 731-734 (2015).

267 10. Diffenbaugh, N.S., \& Ashfaq, M. Intensification of hot extremes in the United States.

268 Geophys. Res. Lett., 37, L15701, doi:10.1029/2010GL043888 (2010).

269 11. Trenberth, K.E., \& Fasullo, J.T. An apparent hiatus in global warming? Earth's

$270 \quad$ Future, doi:10.1002/2013EF000165 (2013).

271 12. Seneviratne, S.I, Donat, M., Mueller, B., \& Alexander, L.V. No pause in the increase

272 of hot temperature extremes. Nature Climate Change, 4, 161-163 (2014).

273 13. Victor, D.G., \& Kennel, C.F. Ditch the $2^{\circ}$ warming goal. Nature, 514, 30-31 (2014). 
274 14. Karl, T.R., et al. Possible artifacts of data biases in the recent global surface warming 275 hiatus. Science, 348 (6242), 1469-1472 (2015).

276 15. Sutton, R.T., Dong, B., \& Gregory, J.M. Land/sea warming ratio in response to

277 climate change: IPCC AR4 model results and comparison with observations. Geophys.

278 Res. Lett., 34, L02701, doi:10.1029/2006GL028164 (2007).

279 16. Herger, N., Sanderson, B.M., \& Knutti, R. Improved pattern scaling approaches for 280 the use in climate impact studies. Geophys. Res. Lett., 42, 3486-3494, 281 doi:10.1002/2015GL063569 (2015).

282 17. Seneviratne, S.I., Lüthi, D., Litschi, M., \& Schär, C. Land-atmosphere coupling and 283 climate change in Europe. Nature, 443, 205-209 (2006).

284 18. Kharin, V.V., Zwiers, F.W., Zhang, X., \& Hegerl, G.C. Changes in temperature and 285 precipitation extremes in the IPCC ensemble of global coupled model simulations. $J$. 286 Climate, 20, 1419-1444 (2007).

287 19. Seneviratne, S.I., et al. Impact of soil moisture-climate feedbacks on CMIP5 288 projections: First results from the GLACE-CMIP5 experiment. Geophys. Res. Lett., $289 \quad 40(19), 5212-5217(2013)$.

290 20. Serreze, M.C., \& Barry, R.G. Processes and impacts of Arctic amplification. A 291 research synthesis. Global Planet. Change, 77, 85-96 (2011).

292 21. IPCC. Climate Change 2014: Synthesis Report. Contribution of Working Groups I, II 293 and III to the Fifth Assessment Report of the Intergovernmental Panel on Climate 294 Change [Core Writing Team, R.K. Pachauri and L.A. Meyer (eds.)], 151 pp. IPCC, 295 Geneva, Switzerland (2014). 
22. Council of the European Union. Climate Change and International Security. http://register.consilium.europa.eu/doc/srv?l=EN\&f=ST\%207249\%202008\%20INIT

$298 \quad$ [accessed 16 November 2015] (2008)

299 23. Kelley, C.P., Mohtadi, S., Cane, M.A., Seager, R., \& Kushnir, Y. Climate change in 300 the Fertile Crescent and implications of the recent Syrian drought. Proc. Natl. Acad.

$301 \quad$ Sci., $112(11), 3241-3246(2015)$.

302 24. Murray, V., et al. Case studies. In: Managing the Risks of Extreme Events and 303 Disasters to Advance Climate Change Adaptation [Field, C.B., et al. (eds.)]. A 304 Special Report of Working Groups I and II of the Intergovernmental Panel on 305 Climate Change (IPCC), pp. 487-542. Cambridge University Press, Cambridge, UK, 306 and New York, NY, USA (2012).

307 25. IPCC. Summary for Policymakers. In: Climate Change 2014: Impacts, Adaptation, 308 and Vulnerability. Part A: Global and Sectoral Aspects. Contribution of Working 309 Group II to the Fifth Assessment Report of the Intergovernmental Panel on Climate 310 Change [Field, C.B., et al. (eds.)], pp. 1-32. Cambridge University Press, Cambridge, 311 United Kingdom and New York, NY, USA (2014).

312 26. Fischer, E.M., Sedlacek, J., Hawkins, E., \& Knutti, R. Models agree on forced 313 response pattern of precipitation and temperature extremes. Geophys. Res. Lett., 314 doi:10.1002/2014GL062018 (2014).

315 This article shows a substantial intermodel agreement of the forced response 316 pattern of precipitation and temperature extremes. 
317 27. Deser, C., Knutti, R., Solomon, S., \& Phillips, A. Communication of the role of

318 natural variability in future North American climate. Nature Clim. Change, 2, 775-

$319779(2012)$.

320 28. Orlowsky, B., \& Seneviratne, S.I. Elusive drought: Uncertainty in observed trends

321 and short- and long-term CMIP5 projections. Hydr. Earth Syst. Sci., 17, 1765-1781,

322 doi:10.5194/hess-17-1765-2013 (2013).

323 29. Lenton, T.M., et al. Tipping elements in the Earth's climate system. Proc. Natl. Acad.

$324 \quad$ Sci., 105, 1786-1793 (2008).

325 30. Church, J.A., et al. Sea Level Change. In: Climate Change 2013: The Physical

326 Science Basis. Contribution of Working Group I to the Fifth Assessment Report of

327 the Intergovernmental Panel on Climate Change [Stocker, T.F., et al. (eds.)], pp.

328 1137-1216. Cambridge University Press, Cambridge, United Kingdom and New York, $329 \quad$ NY, USA (2013).

330 31. Drijfhout, S., et al. Catalogue of abrupt shifts in Intergovernmental Panel on Climate 331 Change climate models. Proc. Natl. Acad. Sci.,

$332 \quad$ www.pnas.org/cgi/doi/10.1073/pnas.1511451112 (2015).

333 32. Sutton, R., Suckling, E., \& Hawkins, E. What does global mean temperature tell us

334 about local climate? Phil. Trans. R. Soc. A, 373, 20140426 (2015).

335 33. Flato, G., et al. Evaluation of Climate Models. In: Climate Change 2013: The

336 Physical Science Basis. Contribution of Working Group I to the Fifth Assessment 337 Report of the Intergovernmental Panel on Climate Change [Stocker, T.F., et al. (eds.)], 338 pp. 741-866. Cambridge University Press, Cambridge, United Kingdom and New 339 York, NY, USA (2013). 
340 34. Taylor, C.M., R.A.M. de Jeu, F. Guichard, P.P. Harris, and W.A. Dorigo. Afternoon

341 rain more likely over drier soils. Nature, 489, 423-426 (2012).

342 35. Mueller, B., \& Seneviratne, S.I. Systematic land climate and evapotranspiration

343 biases in CMIP5 simulations. Geophys. Res. Lett., 41 (1-7),

344 doi:10.1002/2013GL058055 (2014).

345 36. Masato, G., Hoskins, B., \& Woollings, T. Winter and summer northern hemisphere

346 blocking in CMIP5 models. J. Climate, 26, 7044-7059 (2013).

347 37. Hall, A., \& Qu, X. Using the current seasonal cycle to constrain snow albedo

348 feedback in future climate change. Geophys. Res. Lett., 33, L03502,

349 doi:10.1029/2005GL025127 (2006).

350 38. Boisier, J.P, Ciais, P., Ducharne, A., \& Guimberteau, M. Projected strengthening of

351 Amazonian dry season by constrained climate model simulations. Nature Climate

$352 \quad$ Change, 5, 656-660(2015).

353 39. Levy II, H., et al. The role of aerosol direct and indirect effects in past and future

354 climate change. J. Geophys. Res., 118, 4521-4532, doi:10.1002/jgrd.50192 (2013).

355 40. Pitman, A.J., et al. Uncertainties in climate responses to past land cover change: first

356 results from the LUCID intercomparison study. Geophys. Res. Lett, 36, L14814,

357 doi:10.1029/2009GL039076 (2009).

358 41. Luyssaert, S., et al. Land management and land-cover changes have impacts of

359 similar magnitude on surface temperature. Nature Climate Change, 4, 389-393 (2014).

360 42. Jeong, S.-J., et al. Effects of double cropping on summer climate of the North China

$361 \quad$ Plain and neighbouring regions. Nature Climate Change, 4, 615-619,

362 doi:10.1038/nclimate2266 (2014). 
363 43. Wilby, R.L. Constructing climate change scenarios of urban heat island intensity and 364 air quality. Environment and Planning B: Planning and Design, 35, 902-919 (2008).

365 44. Wei, J., Dirmeyer, P.A., Wisser, D., Bosilovich, M.G., \& Mocko, D.M. Where does 366 the irrigation water go? An estimate of the contribution of irrigation to precipitation 367 using MERRA. J. Hydrometeorol., 14, 275-289 (2013).

368 45. Degu, A.H., et al. The influence of large dams on surrounding climate and 369 precipitation patterns. Geophys. Res. Lett., 38, L04405 (2011).

370 46. Orlowsky, B., Hoekstra, A.Y., Gudmundsson, L., \& Seneviratne, S.I. Today's virtual 371 water consumption and trade under future water scarcity. Environ. Res. Lett., 9, 372074007 (2014).

373 47. Hunt, A.S.P., Wilby, R.L., Dale, N., Sura, K., \& Watkiss, P. Embodied water imports 374 to the UK under climate change. Clim. Res., 59, 89-101 (2014).

375 48. Hansen, J., et al. Assessing „Dangerous Climate Change“: Required reduction of 376 carbon emissions to protect young people, future generations, and Nature. PLOS One, $377 \quad 8(12)$, e81648 (2013).

378 49. Tschakert, P. $1.5^{\circ} \mathrm{C}$ or $2^{\circ} \mathrm{C}$ : A conduit's view from the science-policy interface at 379 COP20 in Lima, Peru. Climate Change Responses, 2:3, doi:10.1186/s40665-015$380 \quad$ 0010-z (2015).

381 50. UNFCCC (United Nations Framework Convention on Climate Change). Report on 382 the Structured Expert Dialogue on the 2013-2015 Review (FCCC/SB/2015/INF.1), 383 pp. 1-182. UNFCCC, Bonn, Germany. [available from:

$384 \mathrm{http} / / /$ unfccc.int/resource/docs/2015/sb/eng/inf01.pdf; accessed 16 November 2015] $385 \quad(2015)$ 
386 51. Christensen, J.H., et al. Climate Phenomena and their Relevance for Future Regional 387 Climate Change. In: Climate Change 2013: The Physical Science Basis. Contribution 388 of Working Group I to the Fifth Assessment Report of the Intergovernmental Panel 389 on Climate Change [Stocker, T.F., et al. (eds.)], pp. 1217-1308. Cambridge

390 University Press, Cambridge, United Kingdom and New York, NY, USA (2013).

391 52. Frieler, K., Meinshausen, M., Mengel, M., Braun, N., \& Hare, W. A scaling approach 392 to probabilistic assessment of regional climate change. J. Climate, 25, 3117-3144 393 (2012).

394 53. Schewe, J., et al. Multimodel assessment of water scarcity under climate change.

$395 \quad$ Proc. Natl. Acad. Sci., 111 (9), 3245-3250 (2014).

396 54. Hanewinkel, M., Cullmann, D.A., Schelhaas, M.-J, Nabuurs, G.-J., \& Zimmermann, 397 N.E. Climate change may cause severe loss in the economic value of European forest 398 land. Nature Climate Change, 3, 203-207 (2013).

399 55. Pal, J.S., \& Eltahir, E.A.B. Future temperature in Southwest Asia projected to exceed 400 a threshold for human adaptability. Nature Climate Change, published online, 401 doi:10.1038/nclimate2833 (2015).

402 56. Taylor, K.E., Stouffer, R.J., \& Meehl, G.A. An Overview of CMIP5 and the 403 Experiment Design. Bull. Am. Meteorol. Soc., 93, 485-498 (2012).

404 57. Zhang, X., et al. Indices for monitoring changes in extremes based on daily 405 temperature and precipitation data. Wiley Interdiscip. Rev.: Climate Change, 2, 851$406 \quad 870$, doi:10.1002/wcc.147 (2011). 
407 58. Sillmann, J., Kharin, V.V., Zhang, X., Zwiers, F.W., \& Bronaugh, D. Climate

408 extremes indices in the CMIP5 multimodel ensemble: Part 1. Model evaluation in the

409 present climate. J. Geophys. Res. Atmos., 118, 1716-1733 (2013).

410 59. Sillmann, J., Kharin, V.V., Zwiers, F.W., Zhang, X., \& Bronaugh, D. Climate

411 extremes indices in the CMIP5 multimodel ensemble: Part 2. Future climate

412 projections. J. Geophys. Res. Atmos., 118, 2473-2493 (2013).

413 This article provides time series of climate extreme indices in CMIP5 projections,

414 which have been used as basis for the present analyses.

415 
417 Supplementary Information is available in the online version of the paper.

419 Acknowledgements

420 S.I.S. acknowledges the ERC DROUGHT-HEAT project funded by the European

421 Community's Seventh Framework Programme (grant agreement FP7-IDEAS-ERC-

422 617518). A.J.P. and M.G.D. were supported by the Australian Research Council (ARC)

423 Centre of Excellence for Climate System Science grant CE110001028. M.G.D. was also

424 supported by ARC Grant DE150100456. This work contributes to the World Climate

425 Research Programme (WCRP) Grand Challenge on Extremes. We acknowledge the

426 WCRP Working Group on Coupled Modelling, which is responsible for CMIP, and we

427 thank the climate modelling groups for producing and making available their model

428 output. For CMIP the US Department of Energy’s Program for Climate Model Diagnosis

429 and Intercomparison provides coordinating support and led development of software

430 infrastructure in partnership with the Global Organization for Earth System Science

431 Portals. We are grateful to Nicola Maher for help with processing CMIP5 data. The

432 climate extremes indices calculated for the different CMIP5 runs were obtained from the

433 Environment Canada CLIMDEX website http://cccma.ec.gc.ca/data/climdex/.

\section{Author contributions}

436 S.I.S., M.G.D. and A.J.P. designed the study, following an initial discussion between

437 S.I.S, A.J.P. and R.K. S.I.S. coordinated the conception and writing of the article. M.G.D. 
438 performed the analyses. R.L.W. contributed to the interpretation of regional impacts. All 439 authors commented on the manuscript and analyses.

440

441 Author information

442 Reprints and permissions information is available at www.nature.com/reprints.

443 The authors declare no competing financial interests. Correspondence and requests for

444 materials should be addressed to S.I.S. (sonia.seneviratne@ethz.ch)

445

446 


\section{$448 \quad$ Figure legends}

450 Figure 1. Global mean surface temperature increase as a function of cumulative

451 total global $\mathrm{CO}_{2}$ emissions. This figure from the IPCC WG1 SPM ${ }^{1}$ (Fig. SPM.10) was

452 derived from various lines of evidence. Model results over the historical period (1860 to

453 2010) are indicated in black. The coloured plume illustrates the multi-model spread over

454 the four RCP scenarios. The multi-model mean and range simulated by CMIP5 models,

455 forced by a $\mathrm{CO}_{2}$ increase of $1 \%$ per year is given by the thin black line and grey area. For

456 a specific amount of cumulative $\mathrm{CO}_{2}$ emissions, the $1 \%$ per year $\mathrm{CO}_{2}$ simulations exhibit

457 less warming than those driven by RCPs, which include additional non- $\mathrm{CO}_{2}$ forcings

458 Temperature anomalies are given relative to the $1861-1880$ base period, emissions

459 relative to 1870 .

461 Figure 2. Extreme (and mean) temperature changes associated with $2^{\circ} \mathrm{C}$ target. The

462 figure displays the local changes in (a) hottest daytime temperature (TXx), (b) annual

463 coldest nighttime temperature (TNn), (c) and mean temperature (Tmean) associated with

464 a global warming of $2^{\circ} \mathrm{C}$. The analysis is based on RCP8.5 scenario simulations

465 (ensemble average year: 2044). The respective scaling expressed as ratio of global mean

466 temperature increase is provided in Supplementary Figure S1. Note that very similar

467 results are obtained with the RCP4.5 scenario simulations (Fig. 3 and Supplementary

468 Figures S2 and S3). Figs 2a and 2b also display the outlines of the regions analysed in Fig. 4693. 
471 Figure 3. Scaling between regional changes in annual temperature extremes and

472 changes in global mean temperature, with associated global cumulative $\mathrm{CO}_{2}$

473 emissions targets. See Box 1 for details on the underlying analysis. Results are shown

474 for annual maximum daytime temperature (TXx) in (a) the Mediterranean region (30:45N,

475 10W:45E), (b) the contiguous U.S. (25:50N, 125W:67W), and (c) Brazil (30S:0N,

$47665 \mathrm{~W}: 50 \mathrm{~W})$, and for the annual minimum nighttime temperature (TNn) in (d) the Arctic

477 (65:90N, 180W:180E). The four analysed regions are indicated in Figs. 2a and 2b. The

478 solid black line denotes the ensemble average in the historical runs until 2010 (combined

479 with RCP8.5 for 2006-2010) and the solid red (blue) line denotes the ensemble average

480 of the future projections following the RCP8.5 (RCP4.5) scenario simulations. The red

481 shaded area indicates the total range (minimum to maximum value) between all

482 considered simulations and experiments. The dashed black line shows the 1:1-line. Grey

483 dashed lines show the temperatures $/ \mathrm{CO}_{2}$ emissions associated with $2^{\circ} \mathrm{C}$ increases in

484 global mean and regional extreme temperatures, respectively. Note the different vertical

485 axis for TXx and TNn. Only land grid cells were used for calculating the regional TXx

486 and TNn averages.

487

488 Figure 4. Scaling of 5-day heavy precipitation events with global mean temperature

489 changes, with associated global cumulative $\mathbf{C O}_{\mathbf{2}}$ emissions targets. See Box 1 for

490 details on the underlying analysis. (a) Map of ratio of percentage changes in heavy

491 precipitation events (annual maximum consecutive 5-day precipitation, Rx5day) with

492 changes in global mean temperature for the RCP8.5 scenario simulations (ensemble 
493 average ratio $\Delta \mathrm{Rx} 5$ day $\left./ \Delta \mathrm{T}_{\text {glob }}\right) . \Delta \mathrm{T}_{\text {glob }}$ and $\Delta \mathrm{Rx} 5$ day were calculated from each model run

494 as the difference between the average of the first (1861-1880) and last (2080-2099) 20-

495 year time slices. (b) Scaling of percentage changes in Rx5day in Southern Asia (10:30N,

496 60:110E; see outlined box on Fig. 4a) with global mean temperature changes and

497 cumulative global $\mathrm{CO}_{2}$ emissions. The solid black line denotes the ensemble average in

498 the historical runs until 2010 (combined with RCP8.5 for 2006-2010) and the solid red

499 (blue) line denotes the ensemble average of the future projections following the RCP8.5

500 (RCP4.5) scenario simulations. The red shaded area indicates the total range (minimum

501 to maximum value) between all considered simulations and experiments. Grey dashed

502 lines show the percentage change in $\mathrm{Rx} 5$ day $/ \mathrm{CO}_{2}$ emissions associated with a $2{ }^{\circ} \mathrm{C}$

503 increase in global mean temperature. Only land grid cells were used for calculating the

504 regional Rx5day average. 
506 Box 1: Calculating the relationships among regional extremes, global means, and

507 cumulative emissions.

508

509 We use output from the climate model simulations contributing to the Coupled Model

510 Intercomparison Project Phase $5(\mathrm{CMIP5})^{56}$. Here we present results for climate extreme

511 indices representative of the hottest day (TXx) and coldest night $(\mathrm{TNn})$ of the year, as

512 well as the annual maximum consecutive 5-day precipitation total ( $\mathrm{Rx} 5$ day). Climate

513 extremes indices ${ }^{57}$ were calculated for the historical simulations ${ }^{58}$ and future projections ${ }^{59}$

514 from the CMIP5 ensemble. We use one run (r1i1p1) from models that provide historical

515 simulations during 1861-2005, as well as RCP8.5 and RCP4.5 scenario simulations for

516 the $21^{\text {st }}$ century (see Supplementary Table 1 ). For the analysis of transient changes we

517 concatenated historical (1861-2005) and RCP (2006-2099) simulations. We restricted our

518 analyses to $1861-2099$, which was common to all model runs. Global mean temperatures

519 were calculated as the area-weighted global averages of annual mean temperatures.

520 Extreme indices fields were remapped to a common $2.5^{\circ} \times 2.5^{\circ}$ analysis grid to allow

521 calculation of local ensemble averages and ensure that the same regions from each model

522 contribute to the regional analyses.

523

524 Scatter plots showing the scaling relationship between changes in global mean

525 temperature $\left(\Delta \mathrm{T}_{\text {glob }}\right)$ and regional extremes indices changes (e.g. Figures $\left.3,4 \mathrm{~b}\right)$ are based

526 on decadal averages of the respective variables. These averages of local anomalies

527 relative to the $1861-1880$ average were calculated for moving 10 -year windows, and 
528 moving average values were assigned to the last year of each window period (i.e., the

529 value for year 2010 represents the average during 2001-2010; note that in the case of Fig.

5301 the decadal global temperature averages are assigned to the year directly following that

531 decade). These moving 10-year averages were also used to produce maps of local

532 changes for a global mean temperature increase of $2^{\circ} \mathrm{C}$ (e.g. Figure 2). The indicated

533 cumulative $\mathrm{CO}_{2}$ emissions corresponding to different global mean temperature increases

534 (red tics on horizontal axis in Figures 3 and $4 \mathrm{~b}$ ) were approximated from the RCP8.5

535 ensemble average in Figure 1 (single values were assigned to each of the chosen tic

536 marks). This means, $500 \mathrm{GtC}$ at approximately $1.2^{\circ} \mathrm{C}, 1000 \mathrm{GtC}$ at $2.35^{\circ} \mathrm{C}, 1500 \mathrm{GtC}$ at

$5373.5^{\circ} \mathrm{C}$, and $2000 \mathrm{GtC}$ at $4.45^{\circ} \mathrm{C}$. Respective analyses regarding the scaling of extreme

538 temperatures and precipitation in all 26 regions of the IPCC Special Report on Extremes

539 (SREX) $^{7}$ and the global land are provided in the Supplementary Information.

540

541

542 
Cumulative total anthropogenic $\mathrm{CO}_{2}$ emissions from $1870\left(\mathrm{GtCO}_{2}\right)$

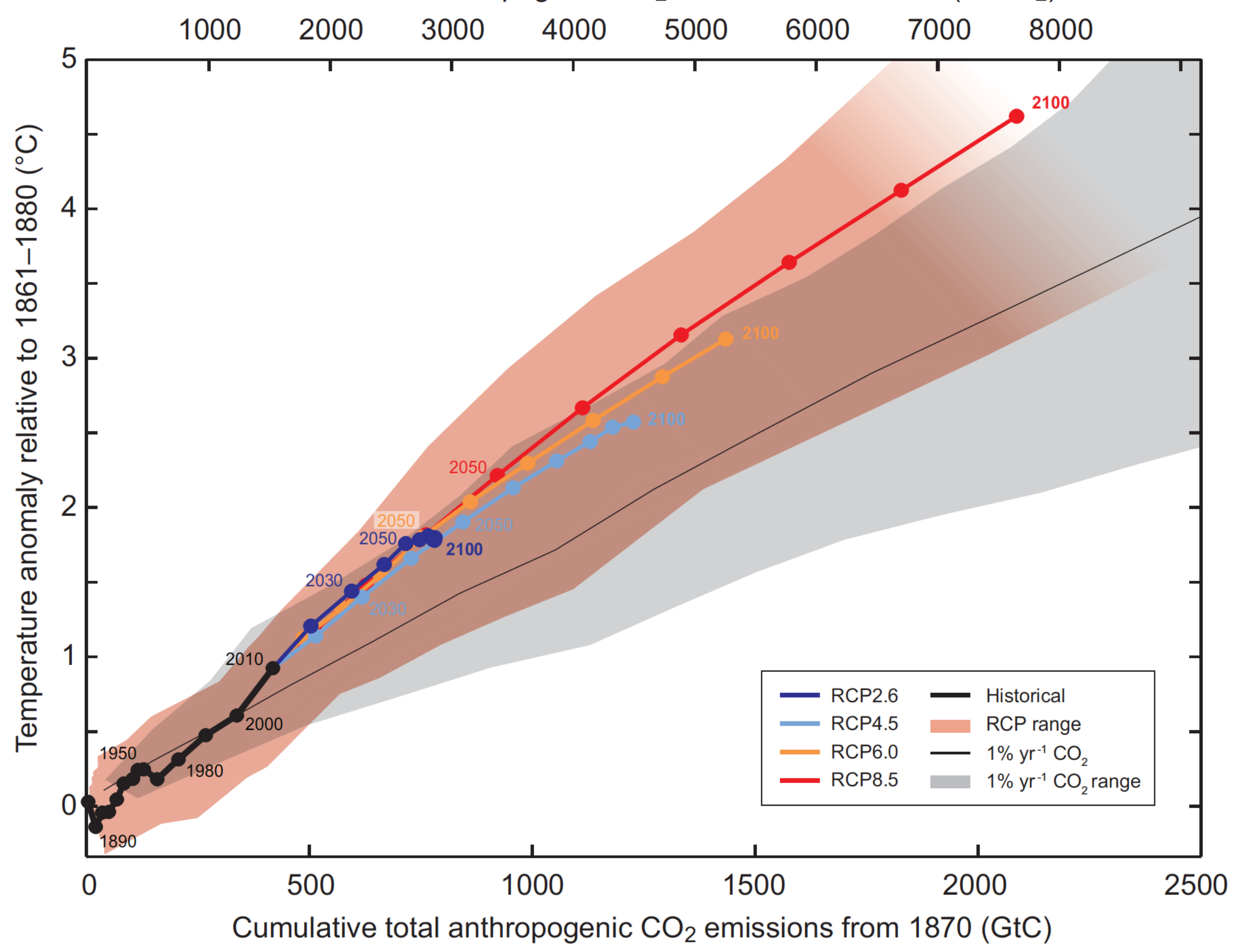


TXx local change when $\Delta \mathrm{T}_{\text {glob }}=2^{\circ} \mathrm{C}$

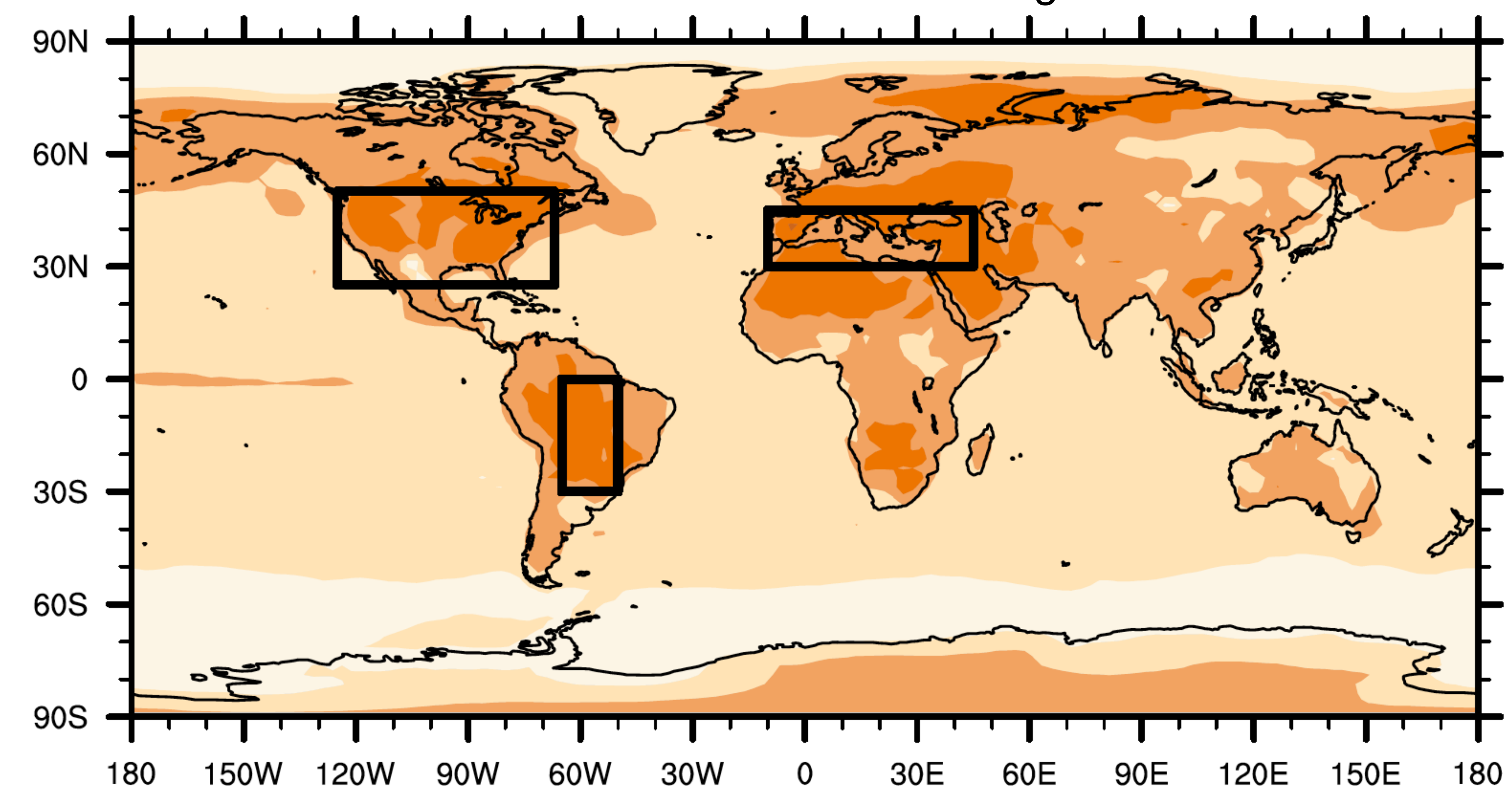

b

$\mathrm{TNn}$ local change when $\Delta \mathrm{T}_{\text {glob }}=2^{\circ} \mathrm{C}$

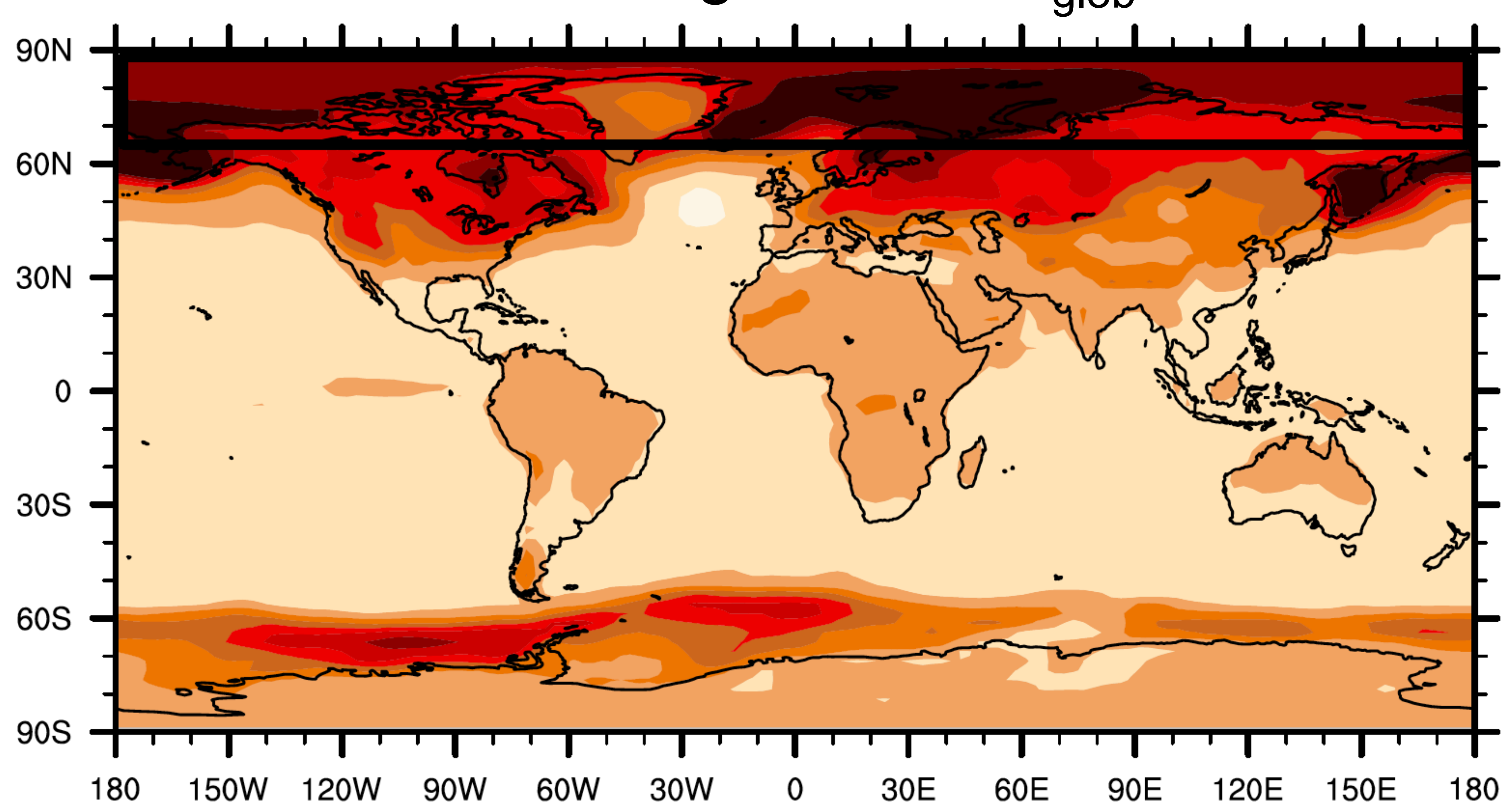

C

Tmean local change when $\Delta T_{\text {glob }}=2^{\circ} \mathrm{C}$

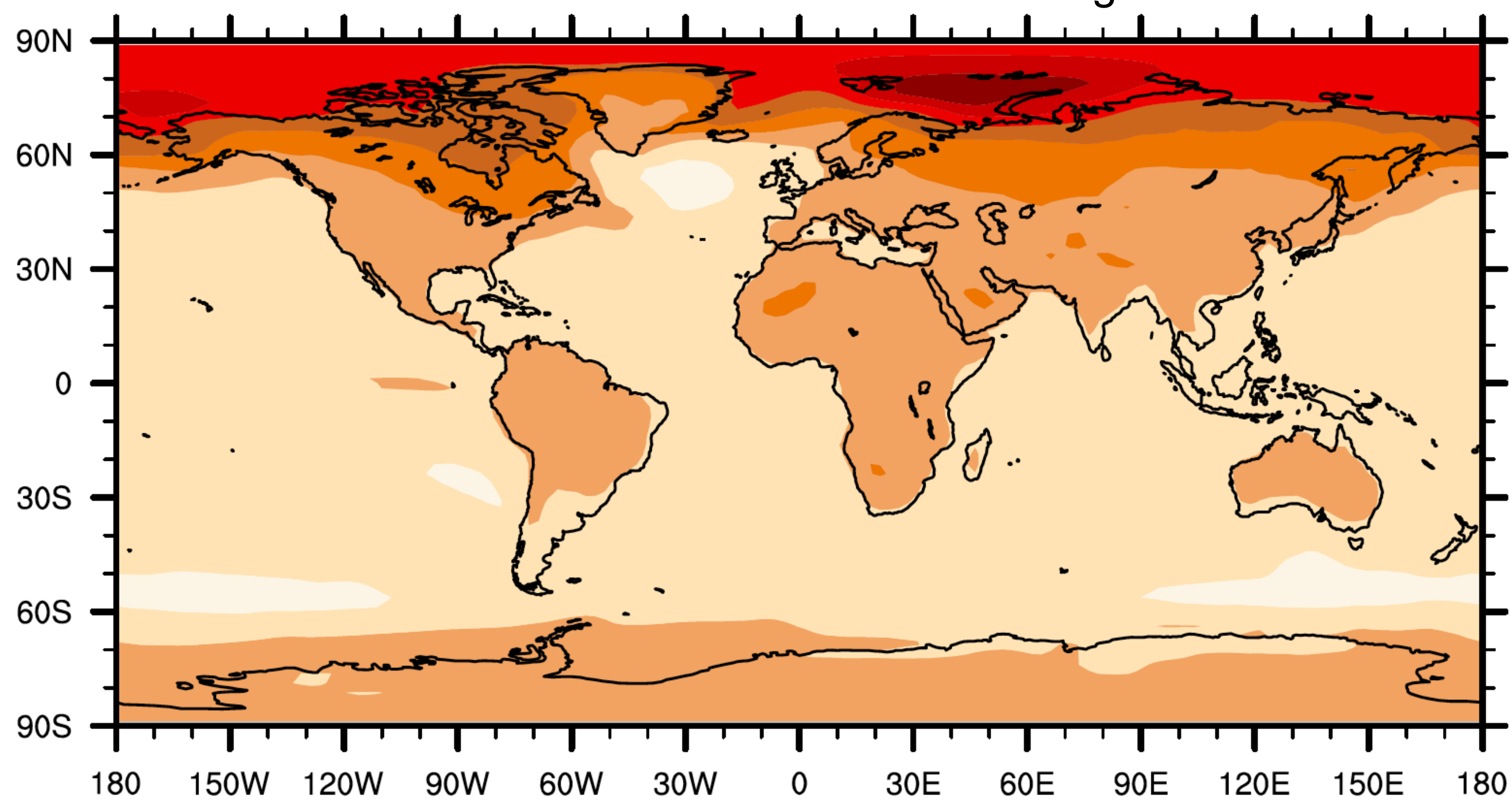

$\left[{ }^{\circ} \mathrm{C}\right]$

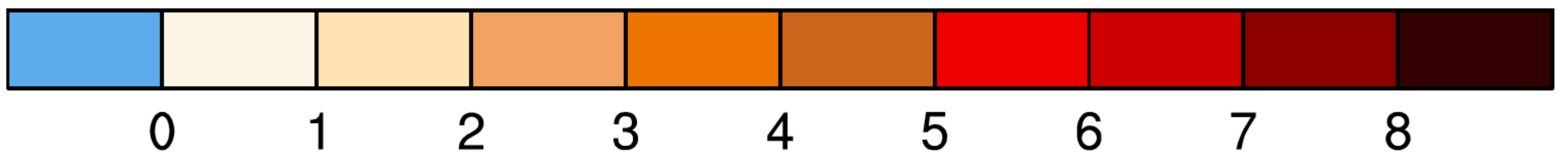


a

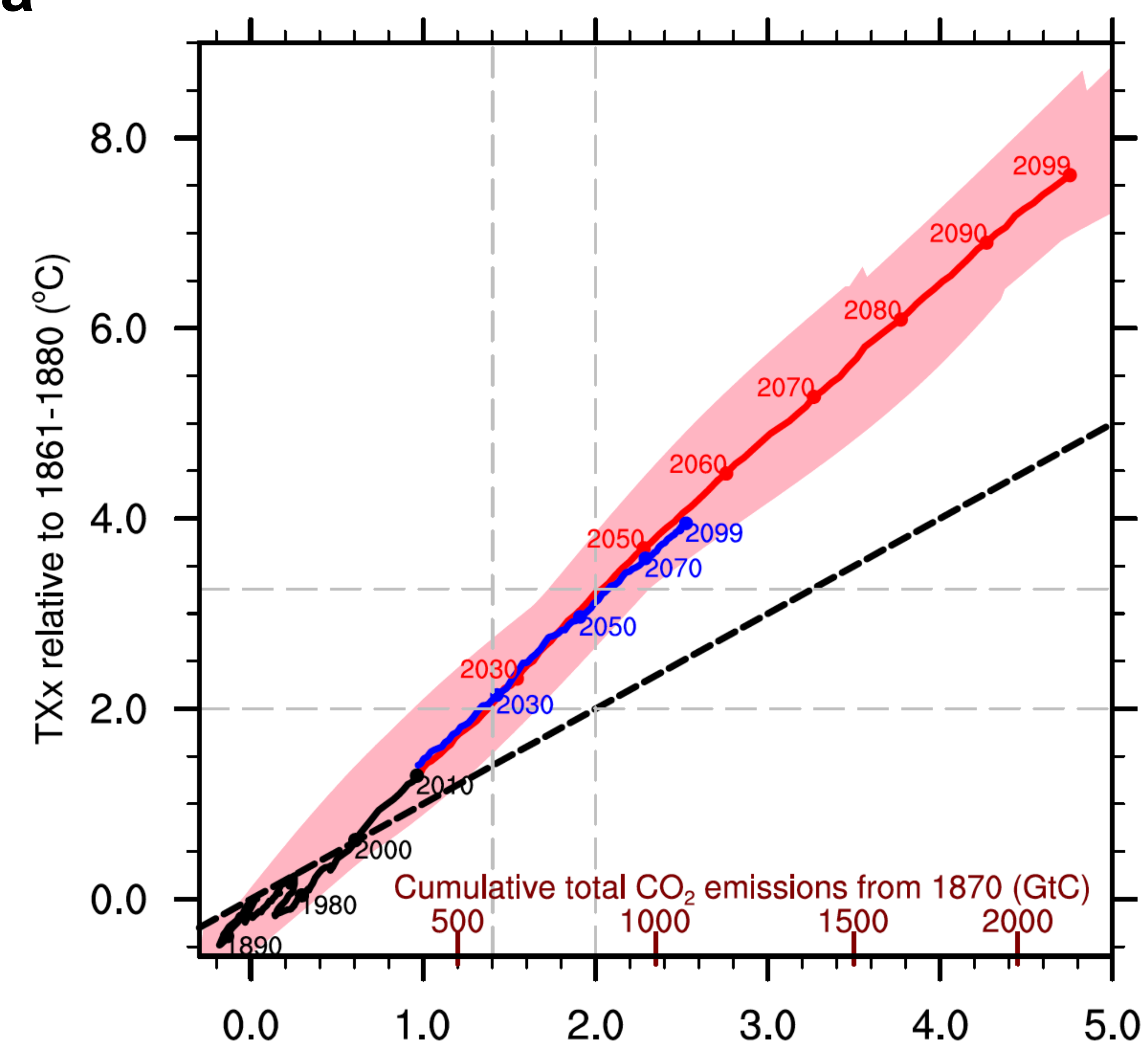

Global mean temperature anomaly relative to $1861-1880\left({ }^{\circ} \mathrm{C}\right)$

C

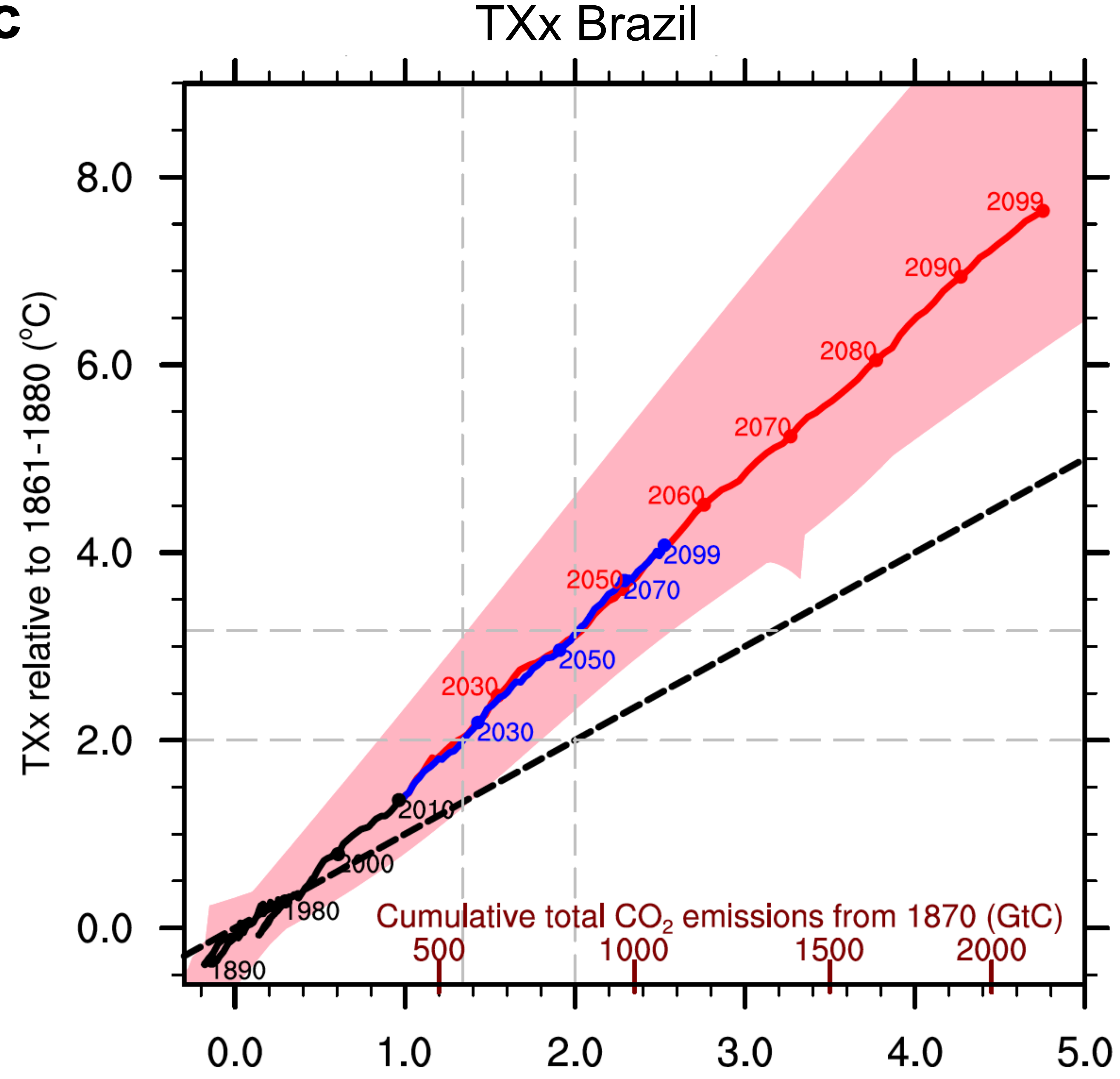

Global mean temperature anomaly relative to $1861-1880\left({ }^{\circ} \mathrm{C}\right)$ b

TXx Contiguous U.S.

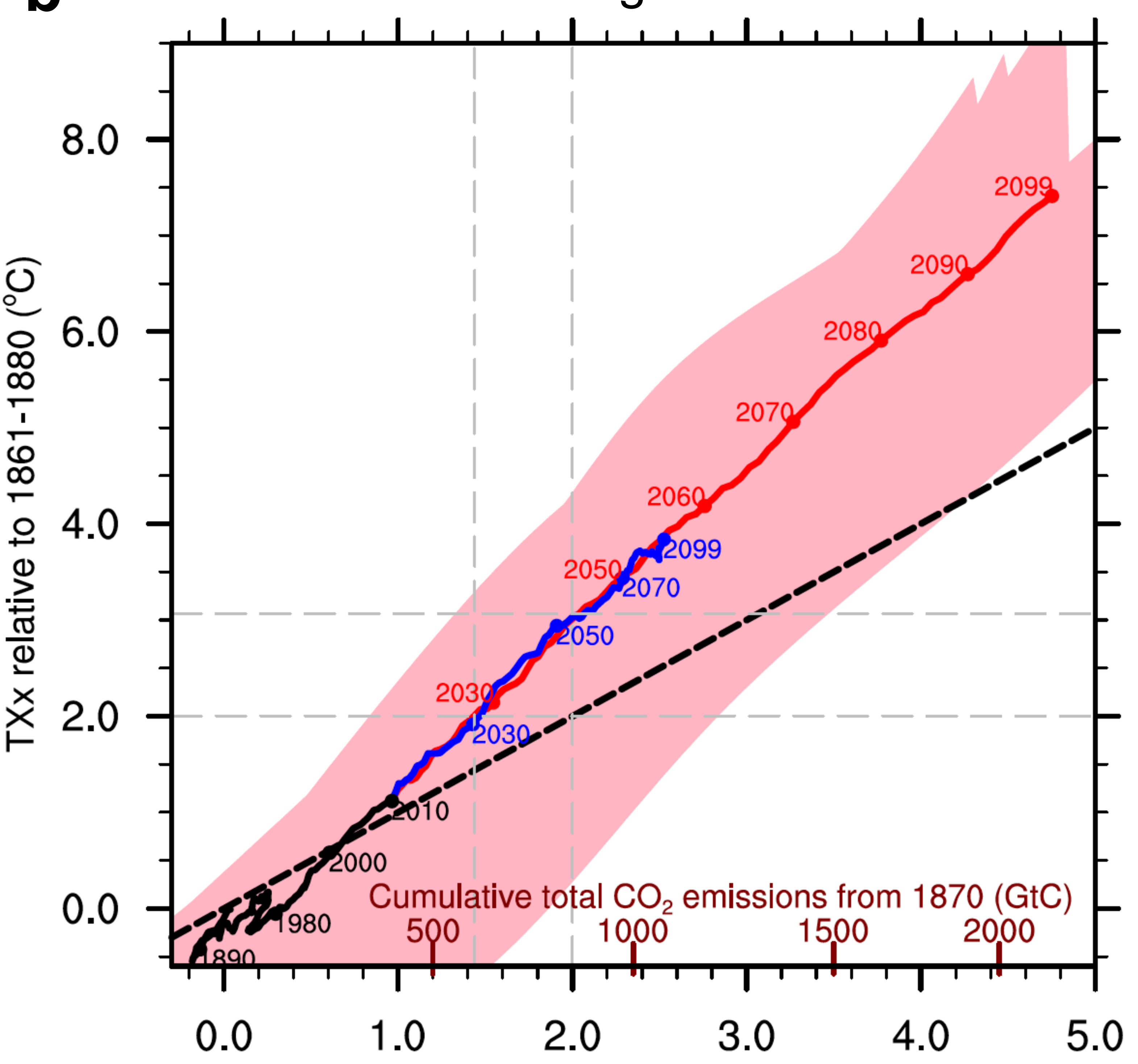

Global mean temperature anomaly relative to $1861-1880\left({ }^{\circ} \mathrm{C}\right)$

d

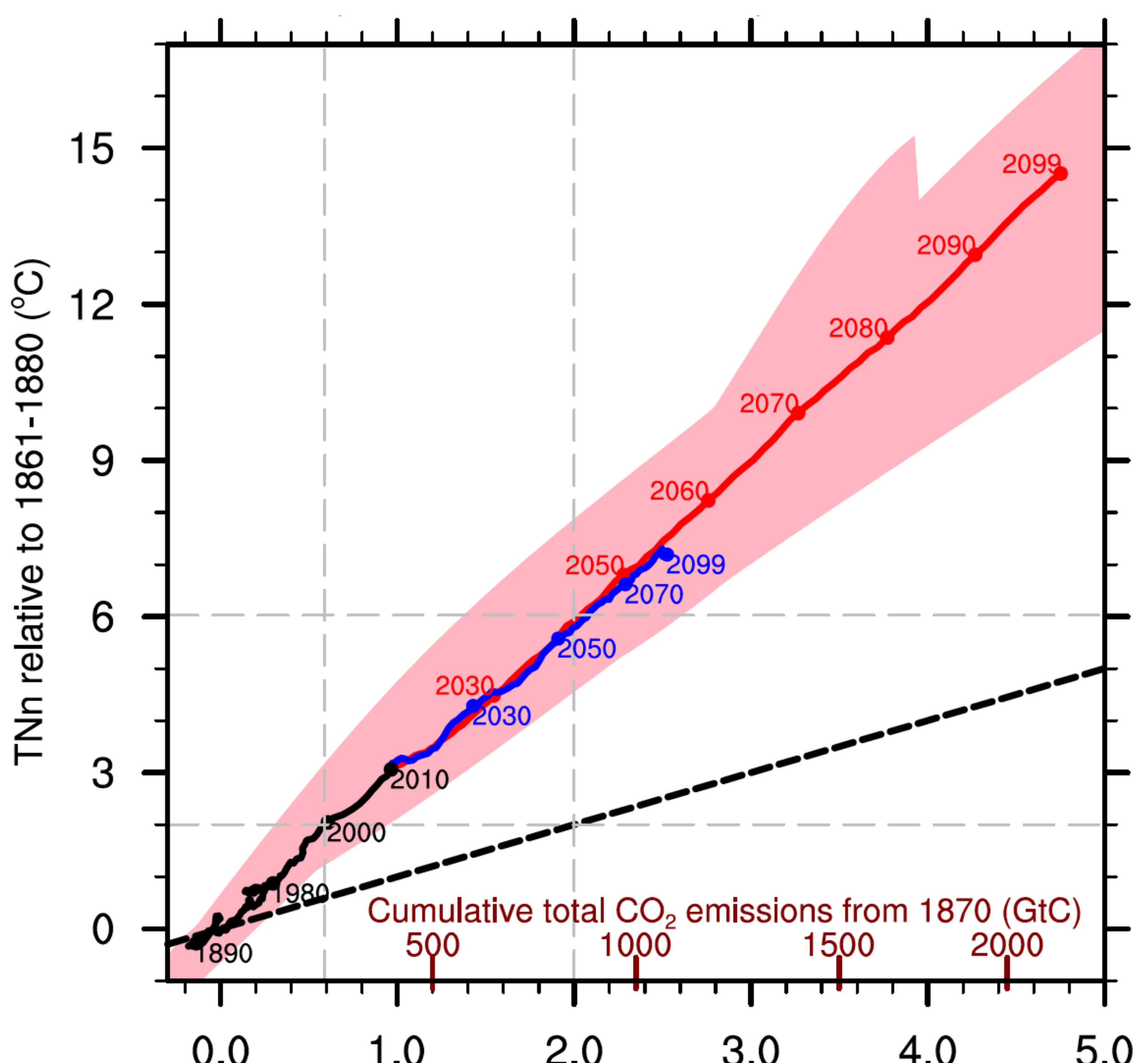

Global mean temperature anomaly relative to $1861-1880\left({ }^{\circ} \mathrm{C}\right)$ 
a

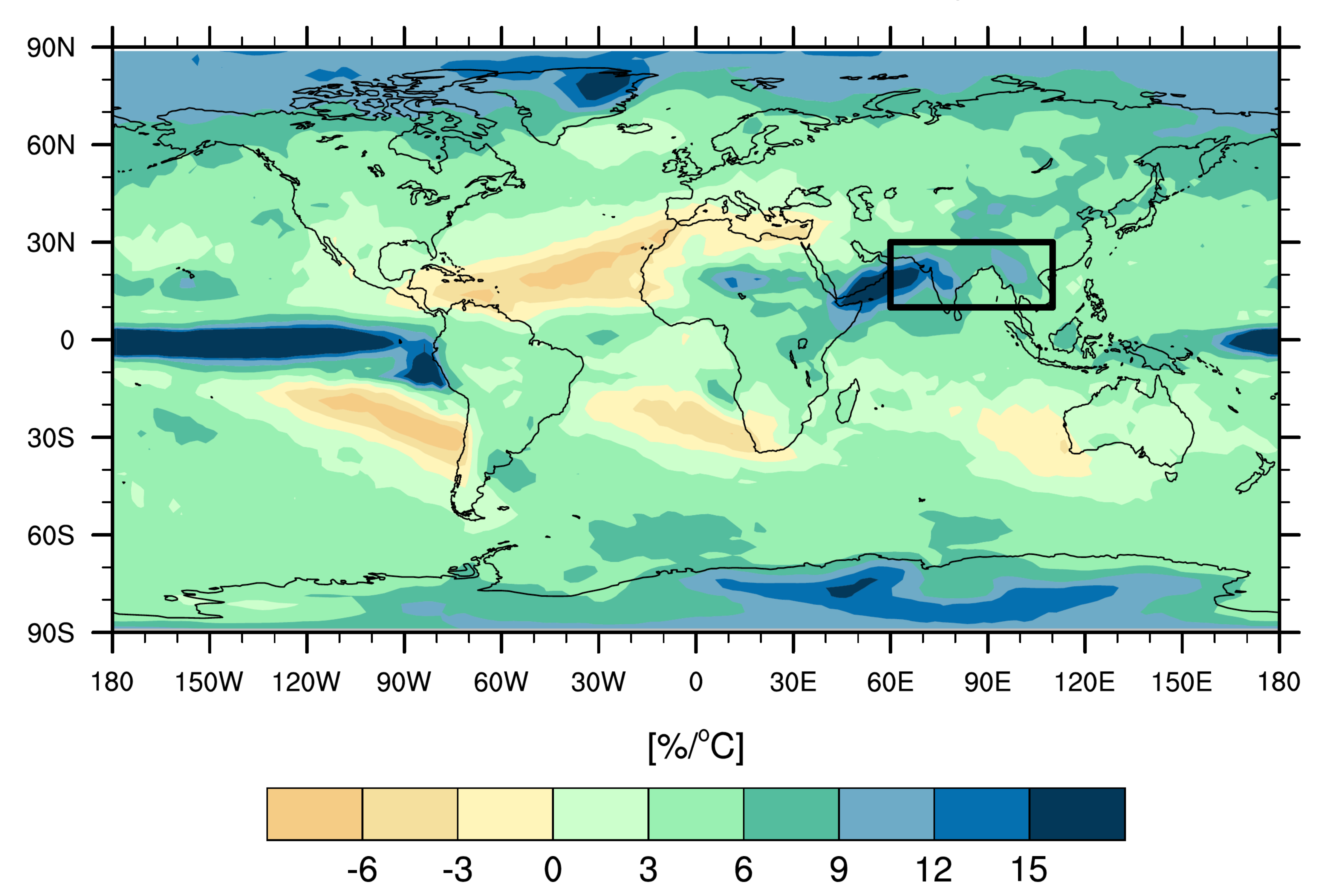

b Rx5day Southern Asia

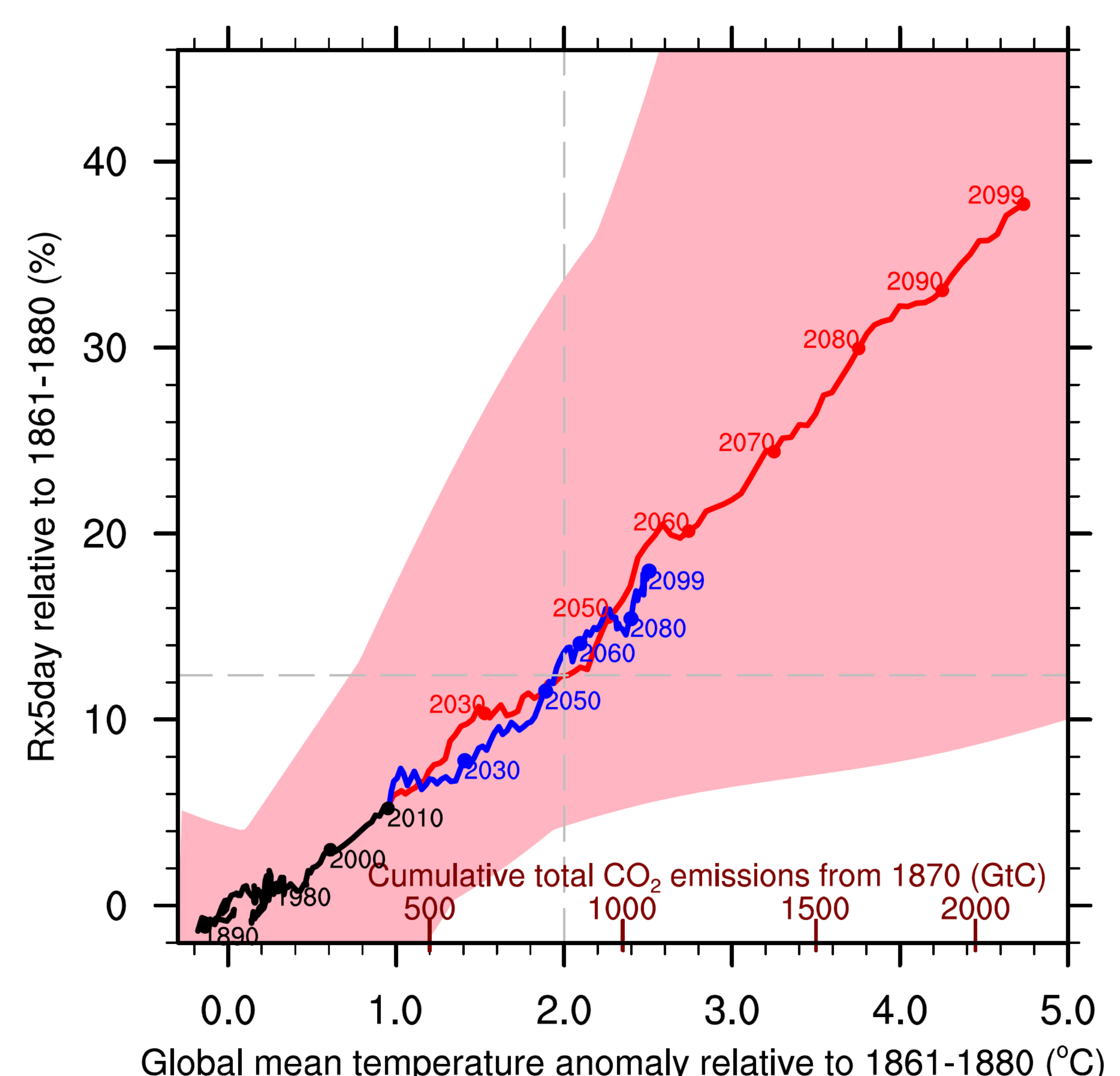

Global mean temperature anomaly relative to $1861-1880\left({ }^{\circ} \mathrm{C}\right)$ 